\title{
Four Econometric Models and Monetary Policy: The Longer-Run View
}

\author{
KEITH M. CARLSON and SCOTT E. HEIN
}

NE key element in the making of an informed economic policy decision is the accuracy with which policymakers can gauge the longer-run consequences of their policy actions and strategies. Crucial to such attempts to grasp these policy consequences is the use of econometric models. Whether current econometric models are useful in this respect depends upon their "long-run" characteristics; unfortunately, until recent$\mathrm{ly}$, there had been virtually no study of the comparative long-run properties of the major econometric models currently in use. Most analyses instead have dealt with how well these models forecast a few quarters ahead.

This situation changed with the publication of a recent study by the Joint Economic Committee (JEC) of Congress that focused explicitly on the economic impact of alternative long-run monetary strategies using three well-known econometric models. ${ }^{1}$ Missing from the JEC study, however, was an econometric assessment using an explicit monetarist model. The purpose of this paper is to extend the JEC study by comparing their results with those obtained for the St. Louis model. Analysis of the St. Louis model according to criteria used in the JEC study is informative for two reasons. First, it indicates whether a monetarist framework provides additional insight into the longrun effects of monetary policy. Second, it provides policymakers the opportunity to compare the long-run properties of a monetarist model with those of the major nommonetarist models.

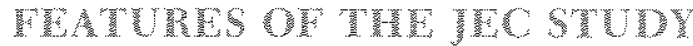

The JEC study examined the simulated performance of certain key macroeconomic variables tnder four different long-run monetary strategies. Three large-scale econometric models were analyzed: those of Chase Econometrics, Data Resources Incorporated

\footnotetext{
${ }^{1}$ Robert $\mathrm{E}$. Weintraub, Three Large Scale Model Simulations of Fon Money Growth Scenarios, a staft study prepared for the use of the Subommittee on Monetary and Fiscal Policy of the font Economic Committee of Congress (Govermment Printing Office, 1982 ).
}

(DRI) and Wharton, the best-known and most widely used models.

Four separate monetary strategies were considered over a 10-year simulation period (1982 through 1991), using the fourth quarter of 1981 and an M1 growth rate of 5.8 percent as points of departure:

(1) a sudden deceleration of $\mathrm{M} 1$ growth to zero percent in one year, and then held at zero;

(2) gradual deceleration of Ml growth to zero percent over a five-year period, and then held at zero;

(3) sudden deceleration of MI growth to 3 percent in one year, and then held at 3 ;

(4) gradual acceleration of MI growth to 10 percent over a five-year period, and then held at 10 .

In addition, each model's proprietor was asked to run a baseline projection with freedom to choose the monetary strategy. ${ }^{2}$

The baseline simulations thus represented each model's assumption about the future course of monetary policy as of March 1982. These assumptions were as follows:

\begin{tabular}{lc} 
& $\begin{array}{c}\text { Ml Growth Rate: } \\
1982-91\end{array}$ \\
\cline { 2 - 2 } Chase & $6.3 \%$ \\
DHI & 4.5 \\
Wharton & 5.2
\end{tabular}

The model propretors were further instructed to simulate each of the four monetary strategies twice: first, without making any judgmental adjestments, and second, making iny adjustments deened necessary to ensure consistency and generate results that were considered sensible. These adjustments were at the eliscretion of the individual model proprietor and involved no contact with the JEC stat. The JEC labeled these two sets of simulations "pure" and "managed."

The JEC study concluded, on the basis of the pure simulations, that none of the models can be used by themselves to decicle among the monetary strategies. "The results of these pure simulations were temed "puzaling," because the links between the noney growth and the key macroeconomic variables ran counter to historical experience.

The JEC conchions about the nanaged simulations were more positive. While there still remained some inconsistencies with historical relationships, the managed simalations were fudged to provide a better basis for considering the longer-nun policy inplications of alternative monetary aggregate growth strategies. Thus, in the discussion to follow, only the managed simulation results from the large scale models are considered. 


\section{The St. Louis Model}

The basic structire of the St I Lours nodel developed in the late $1960 \mathrm{~s}$. has remaned essentially unchanged since then! The model consists of five equations and two identities (see appendix). The foundation of the nodel and the basis for its monetarist label is the GNI' equation. The growth rate of GNP is specifed as a finction of current and lagged values of MI growth and current and lagged values of the growth of high-empley ment federal expentltures The nonetarist label stems primarily from the estimated coefficients: the sum of the coef ficients on noney growth is about unity and the sum of the coefficients on high-employment expenditure growth is about zero.

\begin{abstract}
1 teonall C Andersen and Keith M Carlson, \& Monetanist

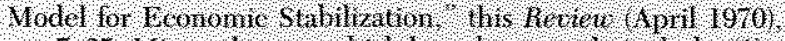

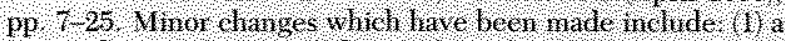

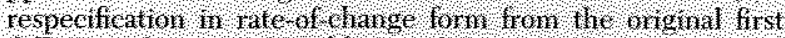
difference form, 2 the addition of energy buces as an exege nous varable. and $(3)$ a change 1 l es timation procedure frem ordman least squares to generalized least stuares for those

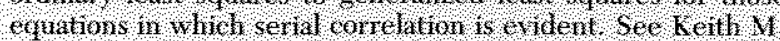

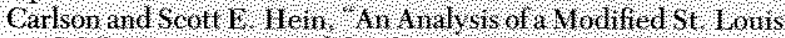
Model a yeper prephred for he Spling Conference on Com paning the Irediche Peffornance of Macroeconomie Wodels at Washington Univerive in St, Lonis (April 20 1982)
\end{abstract}

The price equation relates the rate-of-change of prices to cument and lagged valines of demand presstric current and lagged values of changes in the relative pice of energy, and a measure of anticepated price elange. Demand pressure is defined as flie growth of output relative to the growth of lighemployment output. Anticipated price change is a weighted sum of past price changes with the weights obtained by estinating the comporate Aaa rate as a finction of past inflation. Output growth (real GNP) is determmed residually vis the GNP identity, nominal GNP growth is the sum of real GNP growth and the rate of ehange of prices.

The model's renaining equations provide estimates of three other macroeconomic variables. Unemployment is estimated as a frnction of the gap between actual output and high-employment output. The Aar bond rate is a function of past inflation. The 4-month commercial paper rate is a function of contemporaneous $\mathrm{MI}$ growth and current and lagged values of changes in the relative price of energy output and prices.

respectively, whereas the JEC specified MI targets of zero percent, 3 percent and 10 percent. ${ }^{4}$

Simulation of the St. Louis model for the long-rum monetary strategies outlined in the JEC study required assumptions about other exogenons variables: potential output was assumed to grow 2.5 percent per year, high-employment expenditures to increase at a steady 8 percent rate, and the change in the relative price of energy to be zero. To determine a baseline strategy, an average of the baseline strategies for the large-scale models was constructed. What this amounted to was a gradual reduction in M1 growth from a 5.8 percent rate in fourth quarter 1981 to 5.0 percent in 1991 .

\footnotetext{
MI is an endogenous varible in the model, however, so there is a bisis for compang the Wharton model with the other modets. "The resulting $\mathrm{d}$ l. growth rates were generaly, but not preesely, consistent with the JEC instructions.
} 


\section{PROPRTTIESOF THE MODELS AS REVEAED BY TIY SMUU A TON TESUY res}

This study follows the general format of the JEC study, using the U.S. economic experience from 1956 through 1981 as a guide in comparing the models. If certain systematic relationships among key variables have held over the past 26 years, the simulation results for the next 10 years should be roughly consistent with that experience if one is to place much faith in the model. Deviations from historical experience place the burden of explanation on the individual model proprietor.

Simulation results relating money growth to (1) nominal GNP growth, (2) inflation and (3) real output growth are considered first. Then, the relationships between real output growth and unemployment, and between nominal interest rates and inflation are evaluated. Since the longer-run relationships are of primary interest and since short-run adjustments make the results difficult to interpret, the results for the last five years of the simulations, 1987-91, are investigated.

\section{CNil, Woney and Whochy}

With simulations of the four long-run monetary strategies and a baseline simulation, five observations characterizing the 1987-91 period were generated for each model, providing a basis for examining the relationship between money growth and nominal GNP implicit in each. This relationship is referred to conventionally as the velocity of money. The well-known equation of exchange portrays this as

$$
\mathrm{MV} \equiv \mathrm{Y}, \text { or } \mathrm{V} \equiv \frac{\mathrm{Y}}{\mathrm{M}}
$$

where $M$ is money stock, $Y$ is nominal GNP, and $V$ is the velocity of money. In its growth rate form,

$$
\dot{\mathrm{M}}+\dot{\mathrm{V}} \equiv \dot{\mathrm{Y}} \text {. }
$$

Although velocity growth is influenced by many variables, it has shown considerable stability during the $1956-81$ period. The implication of this stability is that, in the long run, nominal GNP growth is related closely to the growth of M1. The stability of velocity growth further suggests that a 1 percent change in rate of growth of money should coincide generally with a 1 percent change in the rate of growth of nominal GNP.

The large-scale econometric models do not specify GNP as a direct function of money. In these models, money affects GNP indirectly via interest rates and wealth or real balance effects. Despite this, the large models still yield systematic relationships between money and GNP.

Chart 1 summarizes the money-GNP simulation results. Each model is summarized by plotting the average growth of simulated nominal GNP for the 1987-91 period against the average growth rate of $\mathrm{Ml}$ for the same period. Each point represents model results for a particular long-run monetary strategy. ${ }^{5}$ As noted above, these strategies are stated in terms of MI growth, and include (1) a sudden deceleration to zero percent, (2) a gradual deceleration to zero percent, (3) a sudden deceleration to 3 percent, (4) a gradual acceleration to 10 percent, and (5) a baseline strategy chosen by the model proprietor.

The historical line is derived by regressing the fiveyear average growth rate of nominal GNP on the fiveyear average growth rate of $\mathrm{M} 1$. The parallel lines depict the regression estimate plus or minus one standard error of the equation. If velocity growth is totally independent of money growth, then the slope of the historical line would be 45 degrees. The estimated slope, in fact, is not significantly different from 45 degrees.

Comparing the different models with historical experience suggests that none of the large-scale models is generally consistent with the actual past. Only four of the 15 simulated cases for these models fall within the historical band. The DRI and Chase simulations indicate that velocity growth is related negatively to money growth, so that higher rates of money growth do not yield proportionally higher nominal GNP growth. On the other hand, simulation results for the Wharton model indicate that higher money growth results in more than a proportional increase in GNP growth. This result, however. follows from the nature of the financial sector in the Wharton model. On the basis of $\mathrm{M} 2$, which is Wharton's actual monetary target variable, velocity growth is related negatively to money growth as in the Chase and DRI models.

Not surprisingly, the St. Louis model falls clearly within the historical band; after all, the GNP equation

\footnotetext{
5 For the $M 1$ grow th rate associated with cach strategy, refer to the accompanying table. The point on the chat are connected for each model in ascending order of Ml growth. Consequently, the resuls for the Chase and Wharton models are not charted with the JEC's slowest growth strategy farthest to the left. See also footnote 3.
} 


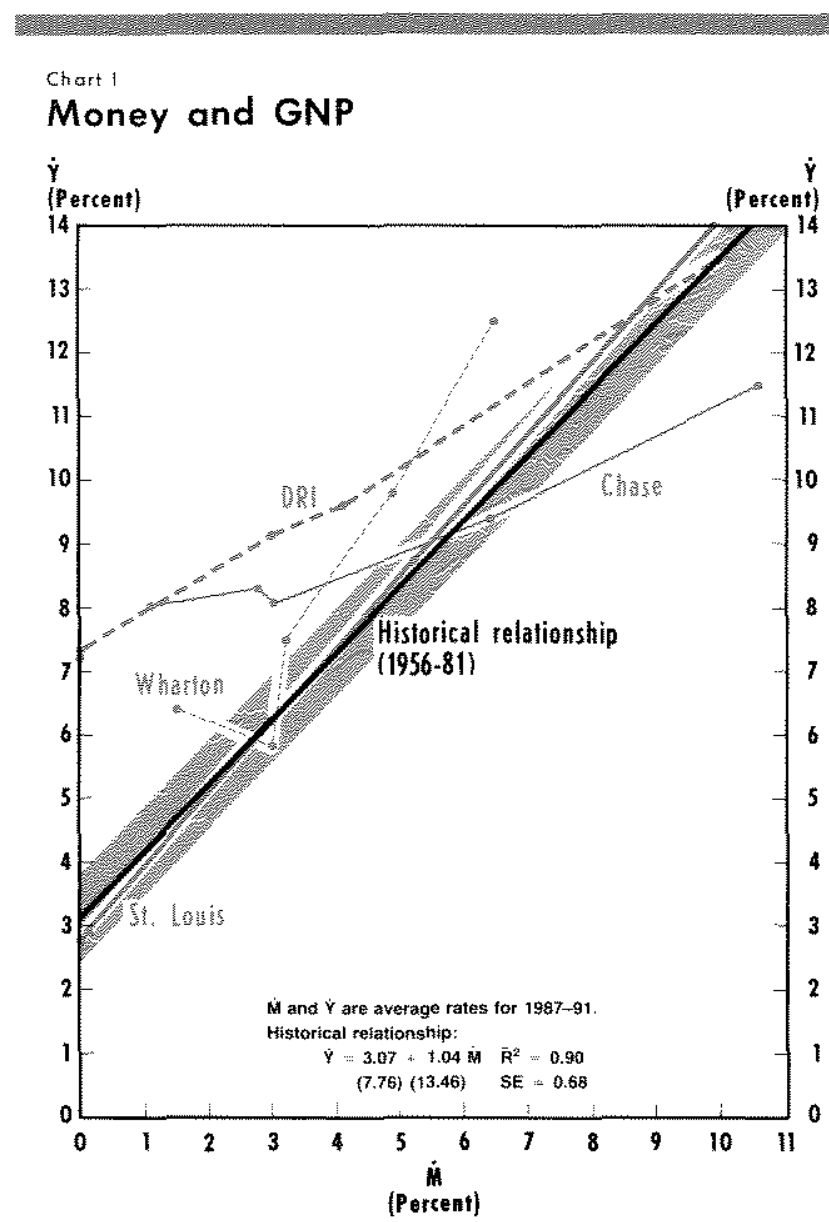

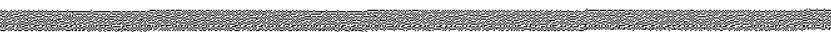

is constructed to be consistent with this historical experience. ${ }^{6}$ The proprietors of the other models offer no explanation as to why their models predict that velocity behavior in the future will be different from the past. ${ }^{7}$

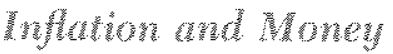

Economists generally agree that, over the long run,

\footnotetext{
The St. Louis model smulations do show a weak positive relationship between velocity growth and money growth. This result occurs because the estimated sum of the coefficients on $M$ in the GNP equation is shightly greater than unity.

Frine JEC study suggests that the reason the large-scale models rm contrary to historical velocity experience is that they are buitt to short-run specifieations, that is, their focus is on forecasting for short periods into the future. Such an explatiation might be appropriate for the Chase nodel, bet the DRl and Wharton models are annual models. The resalts suggest that something more fur damental is awry. In addition, the St. Lous nodel, which is a quarterly model, does not oxhibit any departure from historical long-run velocity behavior.
}

Table 1

GNP, Money and Velocity $(1987-91)$

\begin{tabular}{|c|c|c|c|}
\hline \multirow{2}{*}{ Mocelarid strategy } & \multicolumn{3}{|c|}{ Average Arivel Besults } \\
\hline & W & $y$ & V \\
\hline Chase & & & \\
\hline 1 & $30 \%$ & $8.1 \%$ & $5,1 \%$ \\
\hline 2. & (1) & 180 & 6.9 \\
\hline 3 & 28 & 83 & $\sqrt{5} 5$ \\
\hline 4 & 10.6 & 115 & 10 \\
\hline Daseline & 64. & 94 & 80 \\
\hline Dn & & & \\
\hline 1 & 0.0 & 42 & 172 \\
\hline 2 & 0.0 & 73 & 7,3 \\
\hline 8 & 3.0 & 91 & 60 \\
\hline 4 & 100 & 185 & 32 \\
\hline Baseline & 44 & 9.6 & 83 \\
\hline Wharton & & & \\
\hline 1 & 90 & 56 & 28 \\
\hline 2 & 1,5 & 64 & 48 \\
\hline 3 & 32 & 75 & 4.2 \\
\hline 4 & 65 & 125 & 57 \\
\hline Baseline & 4.9 & 98 & 46 \\
\hline st couls & & & \\
\hline 1 & 00 & 28 & 28 \\
\hline 2 & 01 & 29 & 28 \\
\hline 3 & 30 & 62 & 3.1 \\
\hline 4 & 99 & 140 & 3.7 \\
\hline Baselne & 52 & 87 & 3.3 \\
\hline
\end{tabular}

inflation is related directly to money growth. ${ }^{8}$ In terms of the equation of exchange, with rates of change of prices and output $(\dot{\mathrm{P}}+\dot{\mathrm{X}})$ substituted for $\dot{\mathrm{Y}}$,

$$
\dot{\mathrm{M}}+\dot{\mathrm{V}}=\dot{\mathrm{P}}+\dot{\mathrm{X}} .
$$

A justification of the money-inflation relationship is that $\dot{V}$ and $\dot{X}$ are not related systematically to $\dot{M}$ over the long run. Consequently, variations in $\ddot{M}$ eventually are reflected in $\dot{\mathrm{P}}$.

To evaluate the money-inflation relationship for the different molels, the simulation results are summa-

\footnotetext{
sFor example, Barro and Fischer introduced their 1976 sarvey of monetary theory with the following statement:

"Perhays the most striking contrast between current views of money and those of 30 years ago is the rediscotery of the endogeneity of the price level and intation and their relation to the behavior of money."
}

Robert I. Barro and Stanley Fischer, "Recent Developments in Monetary Theory," Joumal of Monetary Economics (April 1976). p. 133 . 


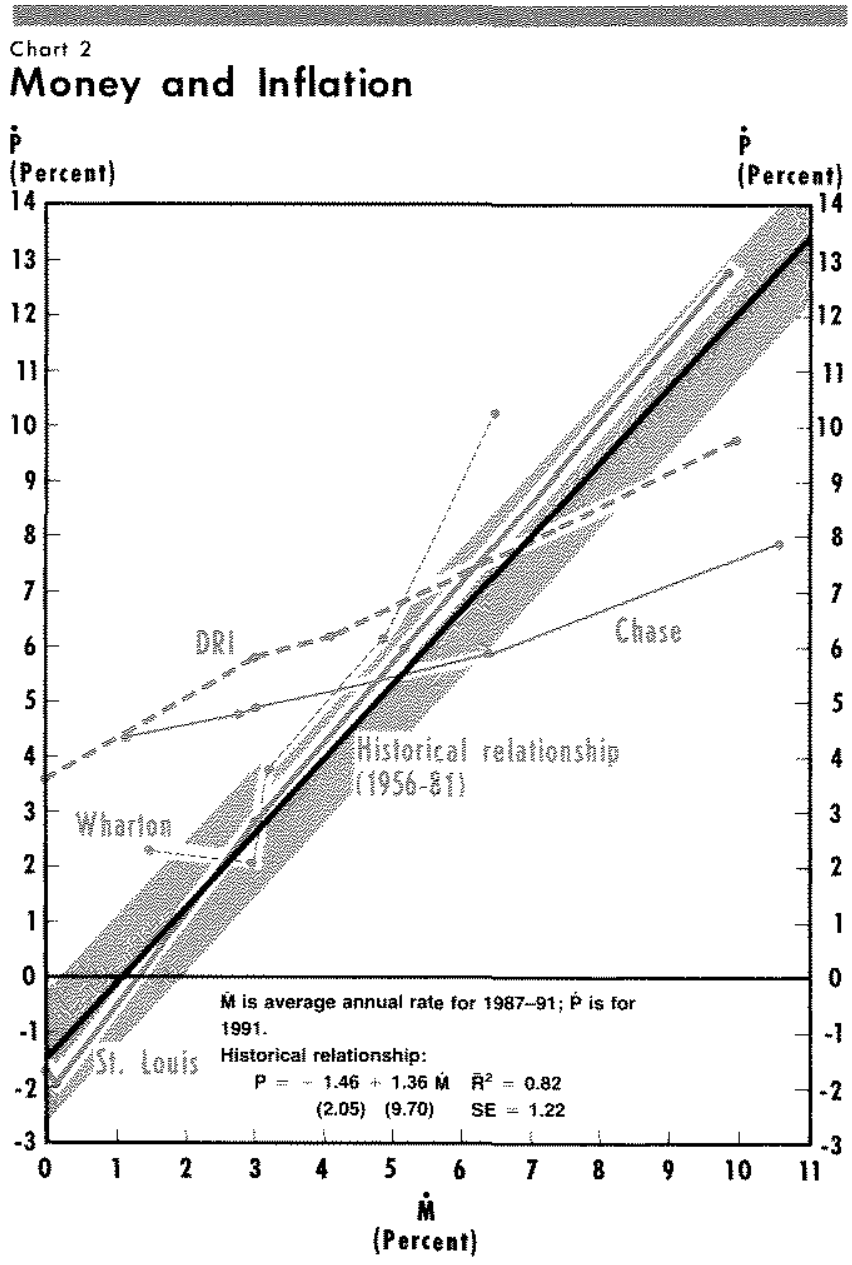

rized in chart 2. Without exception, all four models show a direct relationship between monetary growth and inflation. There is substantial variation, however, in the degree of sensitivity among the models. The Chase model shows a difference in inflation forecasts of only 3.5 percent between the slowest and fastest monetary growth strategies. DRI shows a 6.2 percentage point differential and Wharton a differential of 8.2 percentage points. The St. Louis model shows the largest differential of 14.5 .

To provide a basis for historical comparison, the inflation rate was regressed on the average of money growth over the previous five years for the 1956-81 period. Comparing the simulation results of the four models with this historical line suggests that there is some bias in each. The Chase and DRI models exhibit a sensitivity of inflation to money growth that appears too low, while the Wharton and St. Louis models show

\begin{tabular}{|c|c|c|c|}
\hline \multicolumn{4}{|c|}{$\begin{array}{l}\text { Table } 2 \\
\text { Inflation and loney }(1987-97)\end{array}$} \\
\hline \multirow[b]{2}{*}{ Model and stralegy } & \multicolumn{2}{|c|}{ Average Annual } & Sinal Year \\
\hline & M & P & $P$ \\
\hline \multicolumn{4}{|l|}{ Chase } \\
\hline 14 & $3.0 \%$ & $48 \%$ & $49 \%$ \\
\hline 2 & 14? & 49 & 44 \\
\hline 3 & 28 & 52 & 48 \\
\hline 4 & 106 & 78 & 79 \\
\hline Baselno & 64 & 63 & 59 \\
\hline \multicolumn{4}{|l|}{ DAI } \\
\hline †ै & 00 & 40 & 36 \\
\hline 2 & 00 & 40 & 36 \\
\hline 3 & 30 & 61 & 58 \\
\hline 4 & 10.0 & 10.4 & 98 \\
\hline Baselne & 41 & 65 & 62 \\
\hline \multicolumn{4}{|l|}{ Wharton } \\
\hline 18 & 30 & 29 & 21 \\
\hline 2 & 15 & 34 & 23 \\
\hline 3 & 3.2 & 42 & 3.6 \\
\hline 4 & 65 & 9.8 & 103 \\
\hline Basene & 49 & 60 & 6.2 \\
\hline \multicolumn{4}{|l|}{ St Louis } \\
\hline 1 & 00 & 27 & 17 \\
\hline 2 & 01 & 00 & 39 \\
\hline 3 & 30 & 16 & 28 \\
\hline 4 & 99 & 100 & 128 \\
\hline Baseline & 52 & 52 & 60 \\
\hline
\end{tabular}

a sensitivity that appears too high. While the models generally are inside the historical band for money growth rates in the neighborhood of the 1956-81 average of 4.7 percent, a wide range of results occurs for monetary strategies that lie at the extremes of historical experience. ${ }^{9}$

\footnotetext{
${ }^{9}$ An explanation of these diverse results would require a detailed analy sis of the inner workings of each model. For the most part, the large-scale molels estimate the price level primarily by marking up some measure of labor costs. Consequently, the insensitivity of intlation to money growth developments in the Chase and DRI models might be related to the stickiness of wages. This explanation does not seem to explain the Wharton tesults however. The Wharton model shows considerable sensitivity in the 3 percent to 7 percent range for money growth, yet the price determination process apparently is similar to that for Chase and DRI. The St. Lonis model differs from the large-scale models in that prices are determined directly by demand pressure and past prices. The influence of past prices tends to capture effects operating through wages, yet inflation remains sensitive to money growth throughout the full range.
} 


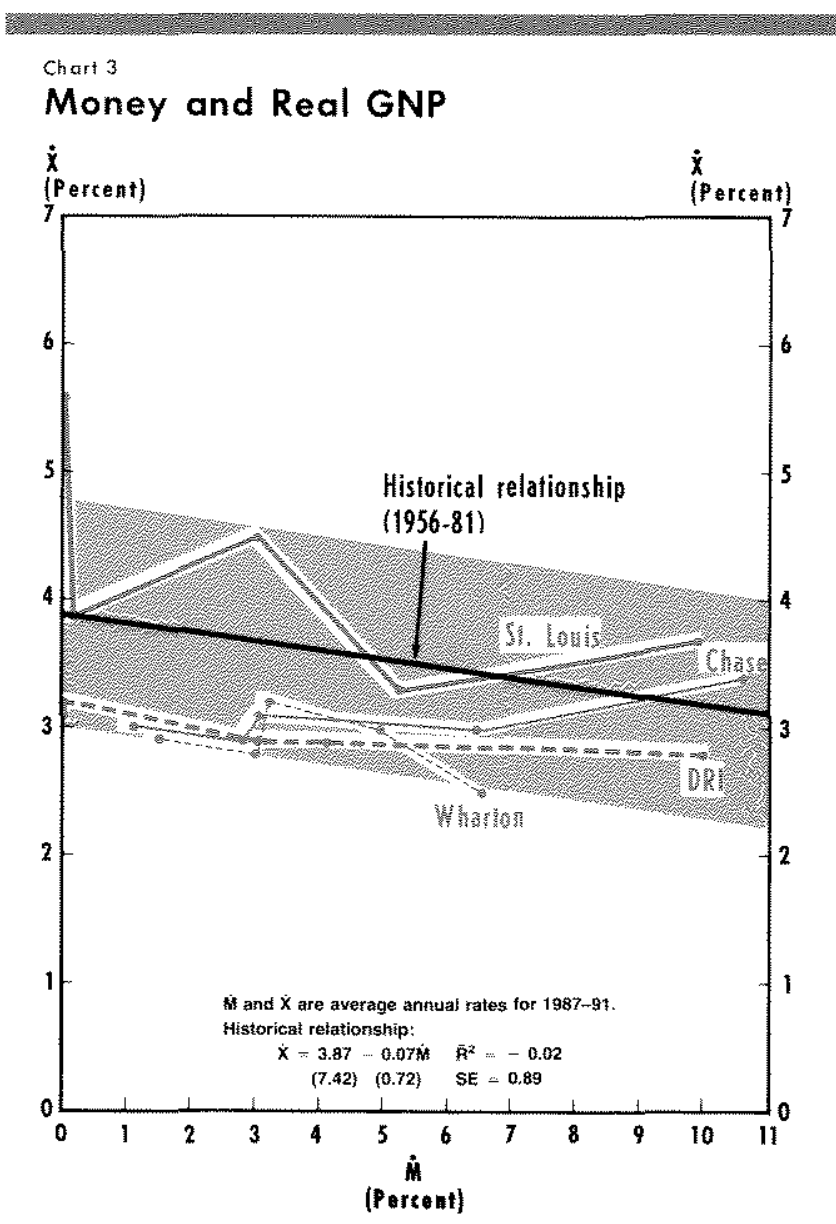

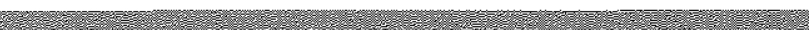

\section{Red GNP and Money}

A corollary to the long-run, money-inflation relationship is the hypothesis that the trend growth of real GNP is not systematically related to long-term money growth. Money may affect the growth of real GNP in the short run, but if inflation rises one-for-one with accelerated money growth, as the equation of exchange indicates, there are no cumulative effects on real GNP.

Chart 3 summarizes the money-real GNP relationship from the simulations of the four models. The three large-scale models all show real GNP growth rates in the neighborhood of 3 percent, regardless of which monetary strategy is considered. The St. Louis model, on the other hand, shows greater variation of real GNP growth among the strategies. This is because the dynamic lag structure of the St. Louis model is such that, after 10 years, the model is still a considerable time away from steady-state equilibrium in growth

\begin{tabular}{ll}
\hline & \\
\hline Table 3 & \\
Real GNP Growth and Money $(1987-91)$ \\
\hline \\
\hline
\end{tabular}

terms. Given more time to adjust, the St. Louis model tends to approach about 3 percent real growth, regardless of money growth.

The historical line in chart 3 is based on five-year growth rates of both money and real GNP. The slope of the line is not significantly different from zero, and the standard error is quite large relative to the mean. The results for the three large-scale models are virtually identical. Relative to the large-scale models, the St. Louis model is the ontlier, though four of the five simulated observations are well within the historical band; only the strategy of sudden deceleration of $\mathrm{M} 1$ to zero yields real output growth that is outside the historical band. Again, this makes sense because of the long adjustment process in the St. Louis model; very weak output growth in the early years under the zero money growth strategy is offset by very strong output growth in the 1987-91 period.

In general, the simulation results suggest that money has a neutral effect on real output growth in the 


\section{Chart 4}

\section{Real GNP and Unemployment Rate}

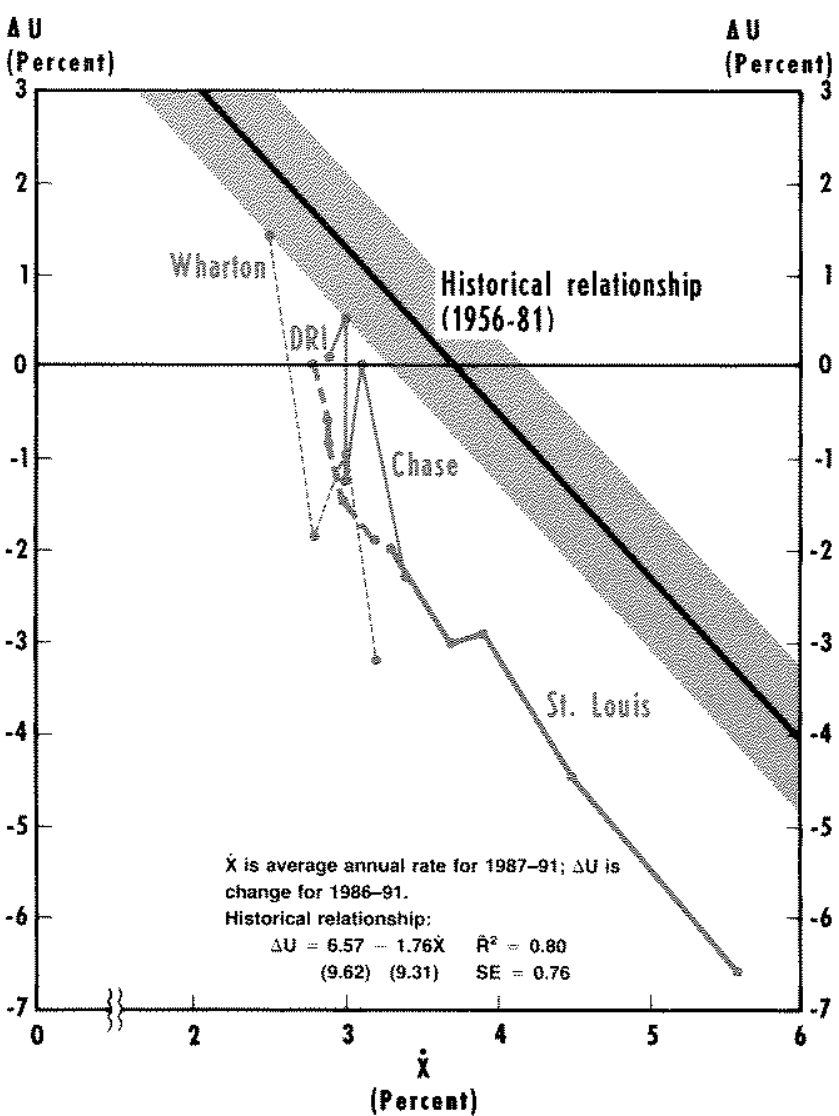

long rin. A sustained change in the money growth rate has little or no effect on the long-run growth rate of real GNP.

\section{Real GNP and Unemployment}

Another relationship of interest in macroeconomics is the one between real GNP growth and the unemployment rate. All three of the large-scale models show essentially the same rates of real growth for each of the monetary strategies. Thus, Okun's law, which relates unemployment to deviations of actual from potential output, suggests that the change in the unemployment rate would be approximately equal for all strategies. ${ }^{10}$

Such is not the case. Each of the large-scale models shows considerable variation in the change in the un-

\footnotetext{
${ }^{10}$ Arthur M. Oknn, "Potential GNP: Its Meastrement and Signifcance," 1962 Proceedings of the Business and Economic Statistics Section of the American Statistical Association, pp. 98-104.
}

Table 4

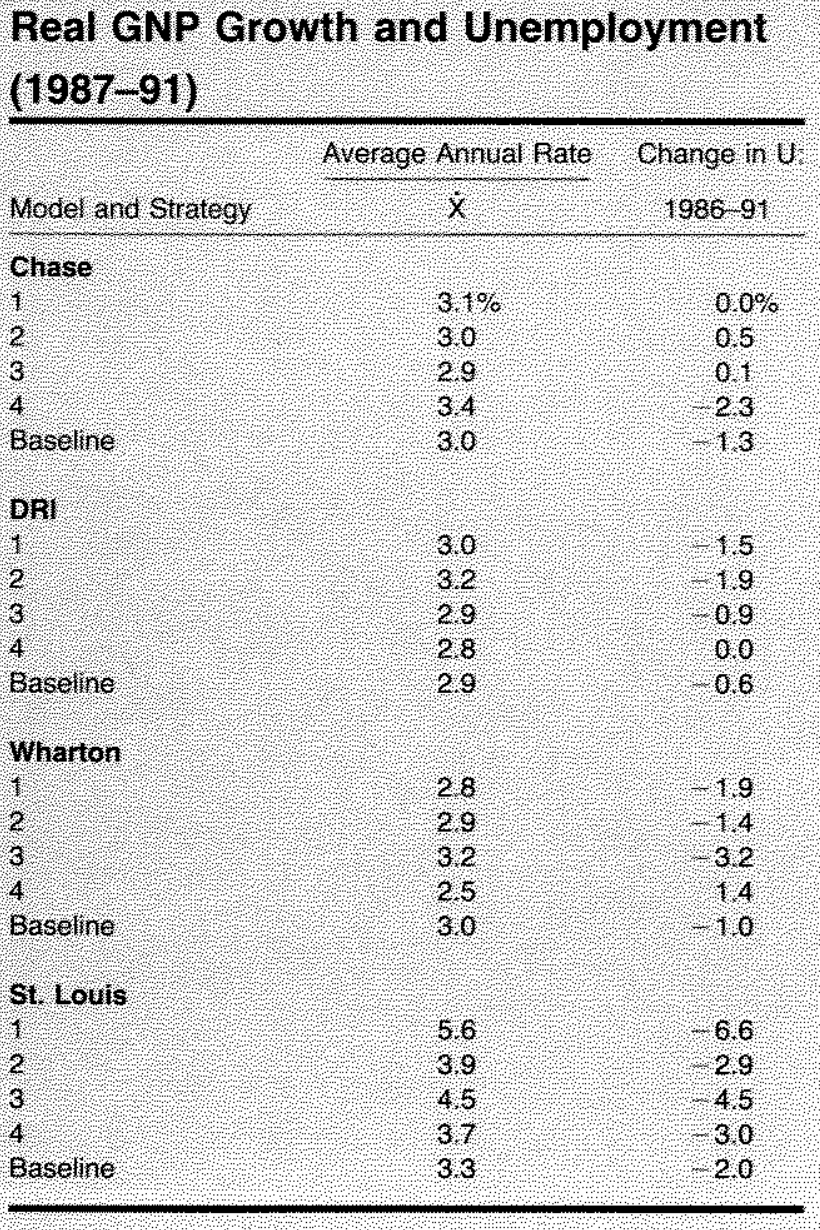

employment rate despite near-equal rates of real GNP growth. What is not known, of course, are the assumed growth rates for the labor force and other determinants of potential output in these models. Nevertheless, when the strategies are compared across models, the results of a sudden deceleration of MI growth to zero range from no change in the unemployment rate for the Chase model to a 1.9 percentage point decline for the Wharton model. The results for the opposite extreme, gradual acceleration of $\mathrm{M} I$ to 10 percent, show even greater variation - from a 2.3 percentage drop in the unemployment rate for the Chase model to a 1.4 point increase for the Wharton model.

The St. Louis model also shows considerable variation in the change in unemployment across monetary strategies; however, this is due to substantial variation in the growth rate of real GNP. All the unemployment changes are negative, because the simulated real growth rates exceed the assumed growth rate of 2.5 percent for potential GNP. Moreover, becalse the St. 


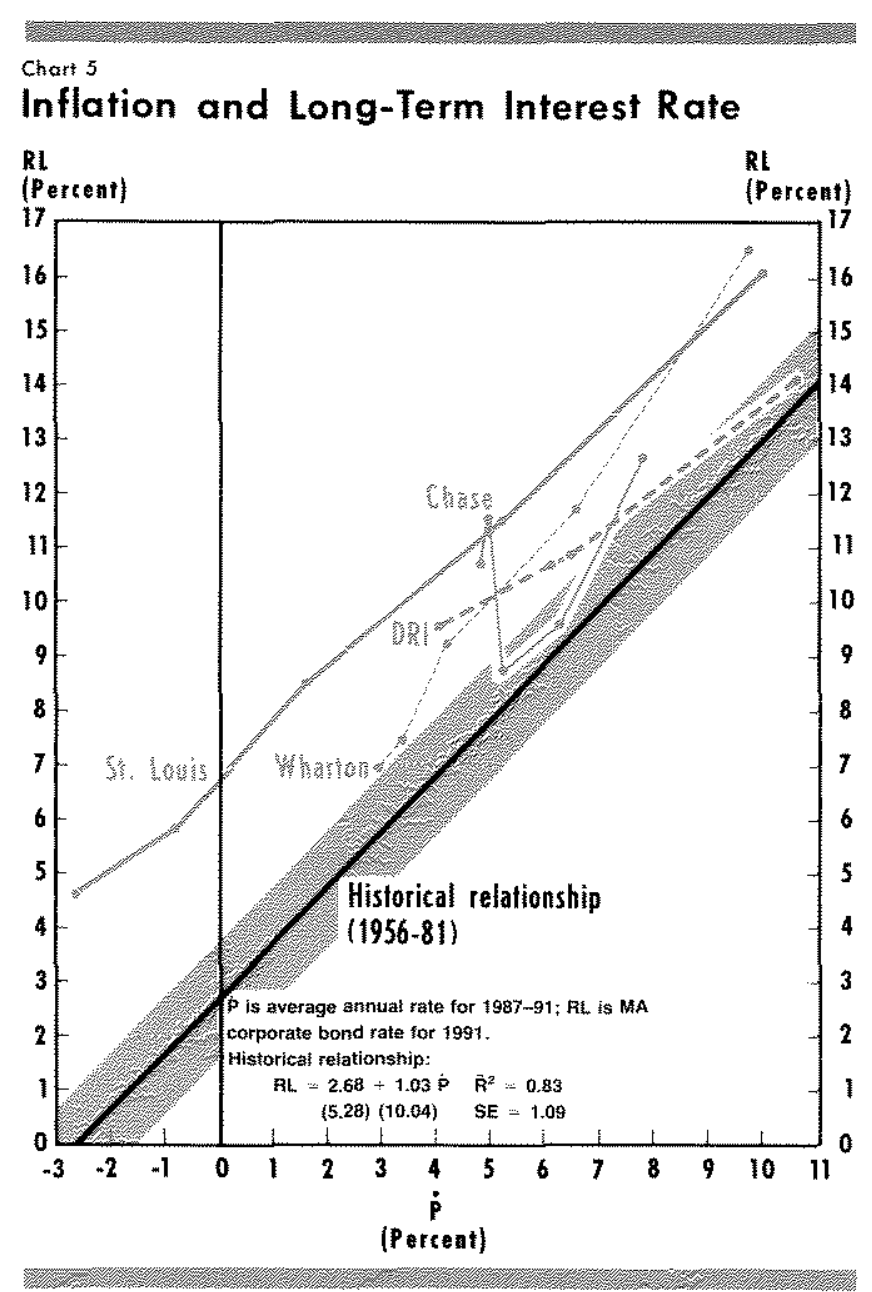

Louis model simulates very strong $1987-91$ real output growth in conjunction with the sudden deceleration of money growth to zero, sizable reductions in unemployment go hand in hand with such a policy.

The historical line in chart 4 is estimated by regressing the change in the unemployment rate over fiveyear periods on the five-year growth rate of real GNP. The historical band encompasses only one observation from the 20 that are charted. The models' failure to replicate history may not be as bad as appears in the chart, however. Potential output supposedly grew faster in the 1956-81 period than it is assumed to be growing in 1987-91. The simulation results suggest an implied growth rate of potential output of 2.5 percent to 3.0 percent for $1987-91$, instead of the 3.6 percent rate calculated for 1956-81. Nevertheless, the largescale models show the inverse relationship between real growth and unemployment suggested by Okun's law. In contrast to the St. Louis model, however, the degree of sensitivity is not well defined.

\begin{tabular}{|c|c|c|c|c|c|}
\hline \multirow{2}{*}{$\begin{array}{l}\text { Model } \\
\text { and strategy }\end{array}$} & \multicolumn{4}{|c|}{ Average Aninual fiesults } & \multirow{2}{*}{$\begin{array}{l}\text { Final Yea } \\
\text { ศL }\end{array}$} \\
\hline & W & P & nt & ns & \\
\hline \multicolumn{6}{|l|}{ Chase } \\
\hline 4 & $30 \%$ & $48 \%$ & $115 \%$ & $163 \%$ & $10,7 \%$ \\
\hline 2 & 11 & 49 & 115 & 158 & 116 \\
\hline 3 & 28 & 52 & 9.5 & 10.6 & 87 \\
\hline 4 & 106 & 78 & 116 & 90 & 127 \\
\hline Baseline & 64 & 60 & 100 & 8.4 & 9.6 \\
\hline \multicolumn{6}{|l|}{ DAI } \\
\hline 8 & 00 & 40 & 101 & 80 & 95 \\
\hline 2 & 00 & 40 & 101 & 78 & 98 \\
\hline 3 & 30 & 61 & 111 & 95 & 107 \\
\hline 4 & 100 & 104 & 148 & 124 & 141 \\
\hline Beseine & 44 & 65 & 114 & 100 & 108 \\
\hline \multicolumn{6}{|l|}{ Wharron } \\
\hline 1 & 30 & 20 & 8.6 & 6.5 & 69 \\
\hline 2 & 15 & 34 & 81 & 62 & 74 \\
\hline 3 & 32 & 42 & 107 & 86 & 92 \\
\hline 4 & 65 & 98 & 160 & 10.8 & 16.5 \\
\hline Baseline & 49 & 66 & 123 & 94 & 117 \\
\hline \multicolumn{6}{|l|}{ St louls } \\
\hline 1 & 00 & 27 & 56 & 19 & 46 \\
\hline 2 & 01 & 009 & 76 & 28 & 58 \\
\hline 3 & 30 & 16 & 8.4 & 49 & 85 \\
\hline 4 & 99 & 100 & 140 & 113 & 161 \\
\hline Bastine & 52 & 52 & 113 & 73 & 115 \\
\hline
\end{tabular}

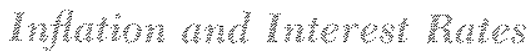

The relationship between inflation and nominal interest rates is the final relationship considered. The inflationary experience of the last 15 years provides an ample basis for examining the nature of this relationship.

Monetary theory suggests that nominal interest rates reflect inflationary expectations. These expectations can be modeled as a function of past inflationary experience. The question examined here is whether the econometric models incorporate such a relationship.

Chart 5 summarizes graphically the simulation results for inflation and long-term interest rates. The Chase model does not appear to show any consistent relationship between inflation and long-term interest rates. The Wharton model displays a peculiar kink at relatively low rates of inflation, while the DRI and St. Louis models display a strong positive relationship. 


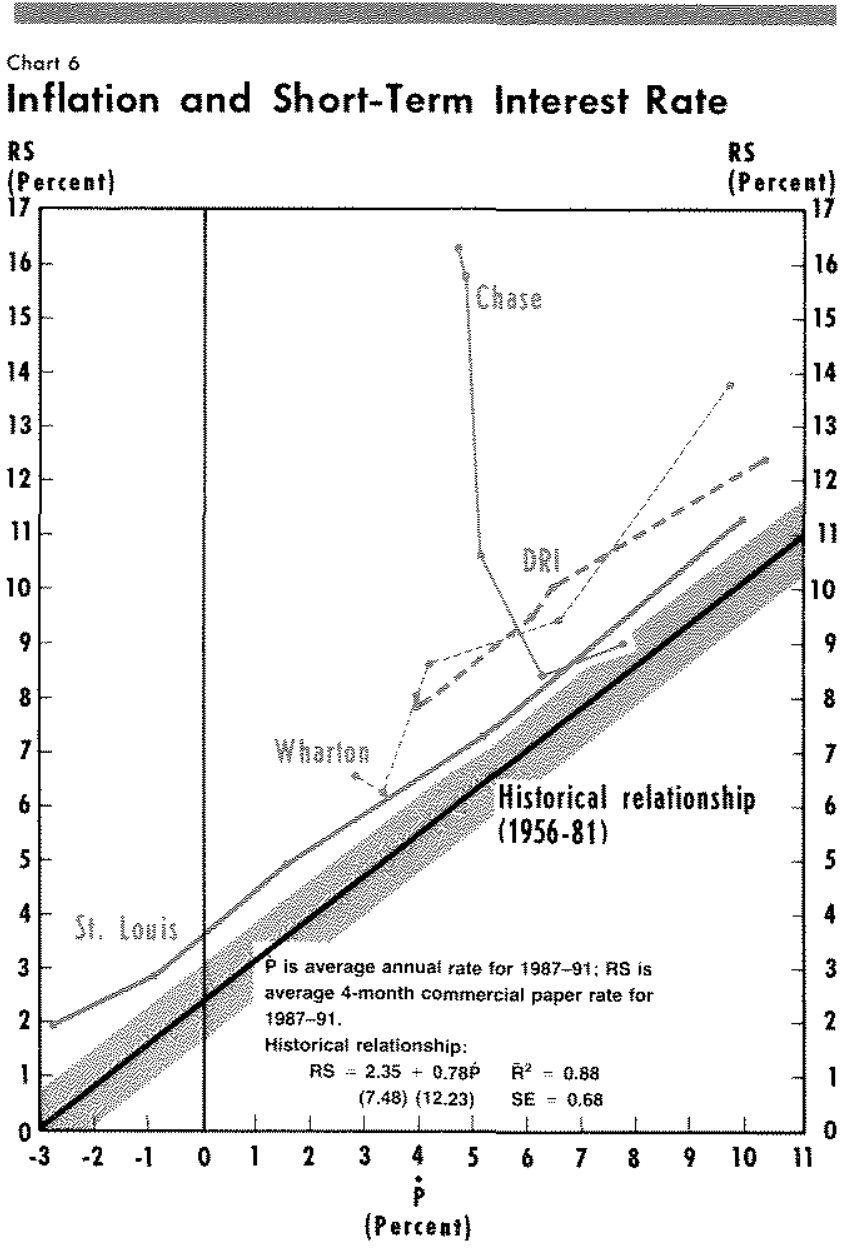

What is most obvious from the chart is the inconsistency with historical experience. The slopes of the simulation results are roughly consistent, but the general level is vastly different. For the St. Louis model, the inconsistency arises because of the use of the serial correlation adjustment in the simulations. With long-term rates in late 1981 well above the inflation rate, this differential only gradually disappears during the simulation period. It appears that the largescale models are following a similar procedure. In this regard, it seems that most of the models would do much better at predicting the change in long-term rates, rather than the level itself.

Chart 6 plots the simulation results for inflation and short-term interest rates. Again, with the exception of the Chase model, the models demonstrate substantial similarities. The St. Louis model tends to simulate the lowest level of short-term rates for a given rate of inflation. The historical line, as in the case of long-term rates, is below all the model results, but the discrepan-

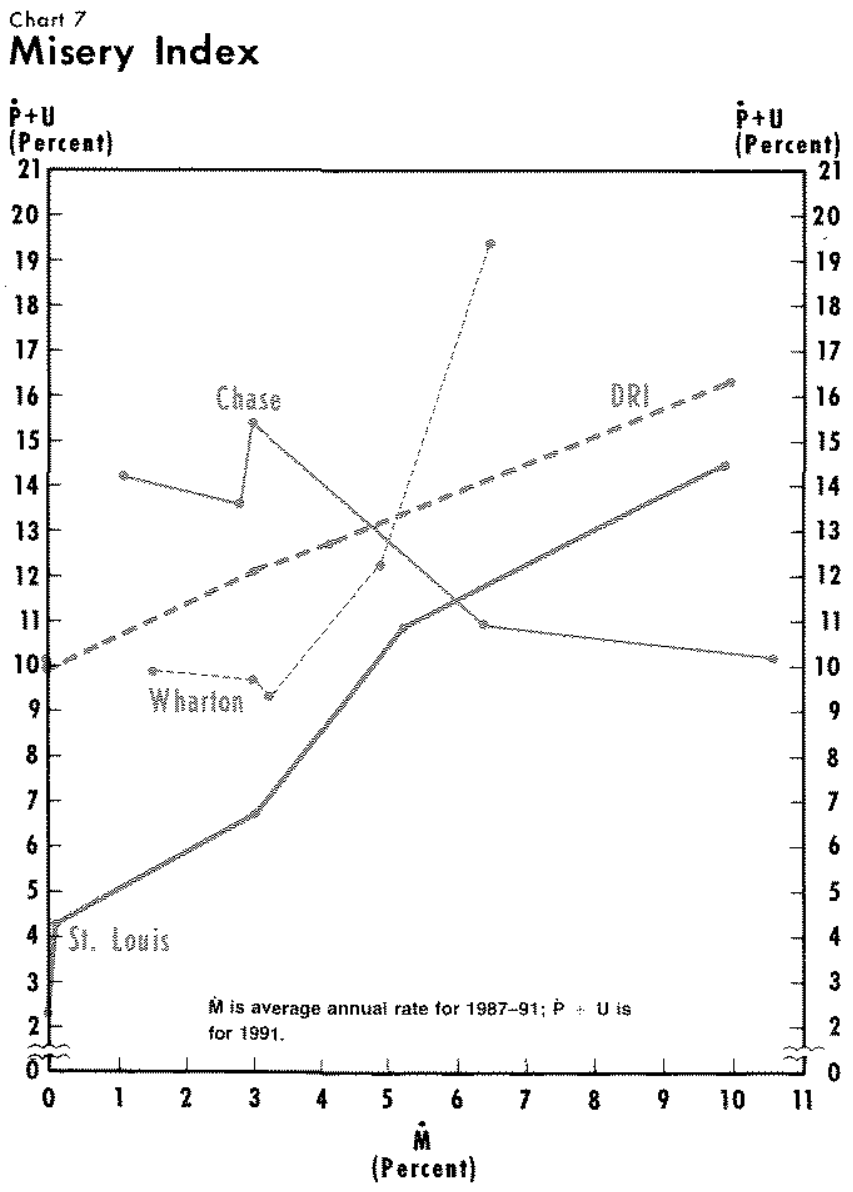

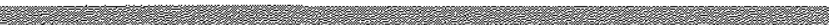

cy is not as great as that for long-term rates. All the models, with the exception of the Chase model, incorporate an inflation premium into short-term rates, suggesting that the lower the inflation rate, the lower short-term interest rates will be.

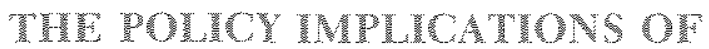 TWES GNULATON WESULTS}

The discussion above emphasized the long-run properties of econometric models as revealed by the simulation results. What remains to be determined are the implications of these results for long-run monetary policy. From this longer-run perspective, do the models simulation results favor a strategy of slow Ml growth, fast Ml growth or something in between?

To aid in this assessment, a crude index, called a "misery index" is constructed to summarize the results. The index is simply the sum of the inflation rate 


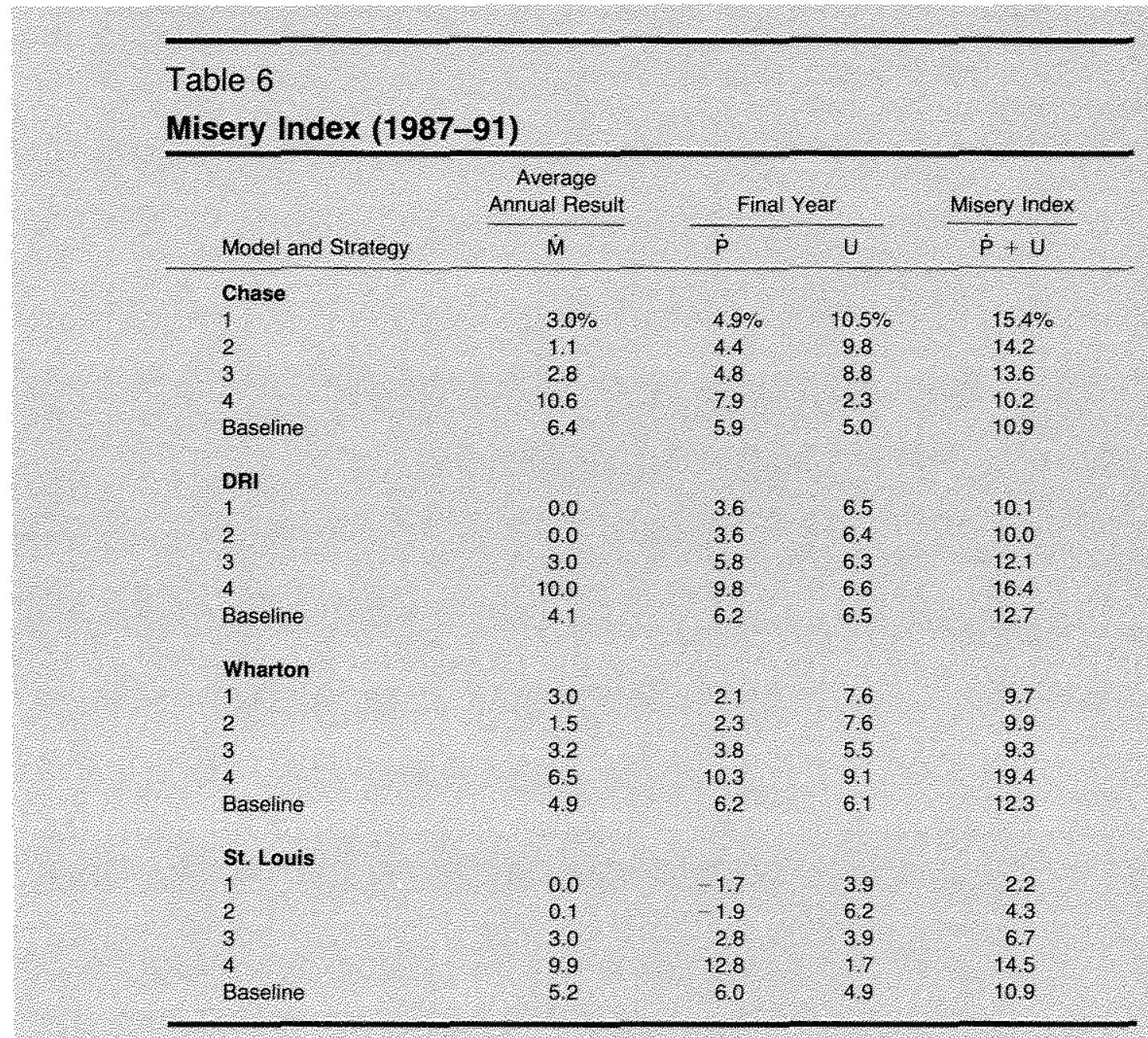

and the unemployment rate at some point in time. 11 Construction of such an index is, of course, simplistic, yet it provides general information for evaluating the effect of the altemative monetary strategies.

Chart 7 summarizes this misery index for the 1987 91 period for the four econometric models. In general, the simulation results indicate that there is a long-run payoff from following a slow Ml growth strategy; the results from the Chase model provide the onty exception. There seems to be little basis for choosing between sudden and gradual deceleration to zero money growth, however, because the misery index differs little when these strategies are compared. An evalua tion of these strategies would involve a more detailed

\footnotetext{
${ }^{11}$ This simple index originated with the late Arthur Okun, al though he called it a "disconfort index." The term "misery index" is used by Jerome L. Stein, Monetarist, Keynesian and New Classical Economics (New York University Press, 1982), p. 159
}

analysis of the adjustment path of inflation and unemployment.

The general levels of the misery index for the four models indicate substantial variation in the predicted effects of alternative monetary strategies. For the slow M1 growth scenarios, the St. Louis model is by far the most optimistic, and the Chase model is the most pessimistic. For the fast Ml growth strategy, Chase is most optimistic and Wharton is most pessimistic. Thus, using this set of results, a policymaker is confronted with a disturbing diversity of opinion. Yet, three of the four models show a definite payoff from following a strategy of slow to moderate growth of $\mathrm{Ml}$.

\section{SUMMARY AND CONCLUSIONS}

This article, extending recent work by Robert Weintraub at the Joint Economic Committee, has compared simulation results from various econometric models to 
the historical record of the last 26 years. The emphasis is on the longer-run economic impact of alternative money growth scenarios. No single model was found to be consistent with the historical record on all counts.

The simulation results generally show, however, the positive consequences of following a slow Ml growth strategy. Higher rates of money growth are associated with higher rates of spending growth, which eventually are reflected in higher inflation rates. U sing a simple social loss function called the misery index, three of the four models indicate that, over the long run, unem- ployment gains, if any, are insufficient to offset the increase in inflation.

Consequently, this article - like the JEC study before it - concludes that there are no long-run economic gains from higher rates of money growth. This is true even though the models run counter to historical experience in some important aspects. Moreover, the results indicate that higher inflation rates are associated with higher levels of both short-and long-term interest rates, so that interest rates tend to be higher when the faster monetary strategies are followed. 


\section{Appendix \\ Revised Form of St. Louis Model}

The version of the St. Louis model used for the simulations in this article is summarized in table 1 , with the coefficien ts given in table 2. Equations 1-4 are estimated with Almon constraints on the coefficients.

\section{Table 1}

\section{The Model}

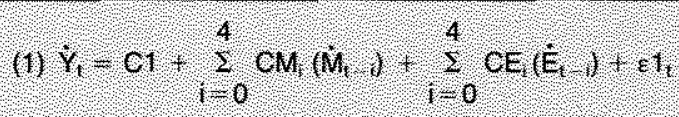

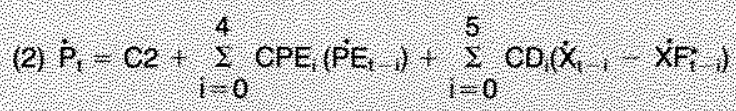

$$
\begin{aligned}
& \text { I CPA (PA) + CDUM (DUMT) } \\
& + \text { CDUM2 (DUM2) + } 82
\end{aligned}
$$

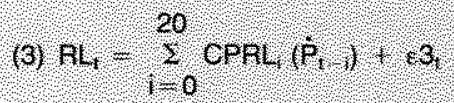

$$
\begin{aligned}
& \text { (4) RS, } 2 \text { ? } 2 \text { CPEAS }\left(P_{\text {E }}, \text { i) }+\right. \text { CMAS (M) }
\end{aligned}
$$

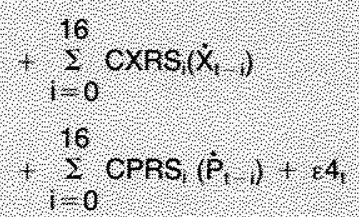

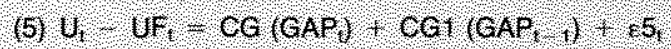

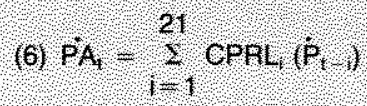

(7) Y. $\cup(\mathrm{P}, 100)\left(\mathrm{X}_{\mathrm{t}}\right)$

(8) $\left.Y_{1}=\left(Y_{1} Y_{i},\right)^{4}-1\right) \cdot 100$

(9) $\left.x,\left(x_{1}, x_{-},\right)^{4}-1\right) 100$

(10) $\left.P,=(P, P,)^{4}-1\right) 100$

(11) $\mathrm{GAP}=(\mathrm{XF}, \quad \times) \times F)=100$

(12) $\left.X F_{i}=\left(X F, X_{t},\right)^{4}-1\right) 100$
Equation 5 is estimated with ordinary least squares. Three eharacteristics differentiate this model from the original version published in 1970: (1) most variables are entered in rate-of-change form rather than firstdifference form; (2) the demand slack variable is entered in real rather than nominal terms; and (3) where relevant, the model's equations have been corrected for serial correlation problems.

\section{Table 2}

\section{In-Sample Estimation: 1/1955-W/1981 (absolute value of t-statistic in parentheses)}

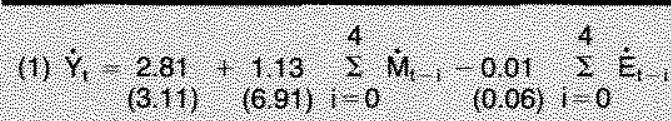

$$
\begin{aligned}
& \mathrm{h}^{2}=0.40 . \mathrm{sE}=3 . \mathrm{2} \text {. } \mathrm{DW}-2.13
\end{aligned}
$$

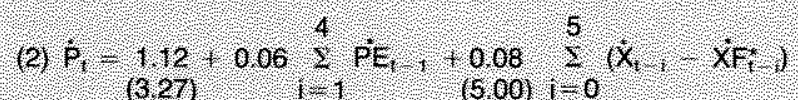

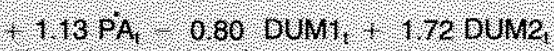

$$
\begin{aligned}
& (1,44) \text {. }(1,33) \text { ? ४ ? }(2,79)
\end{aligned}
$$

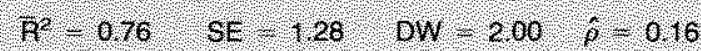

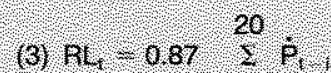

$$
\begin{aligned}
& 1050) 1.0 \\
& \mathrm{P}^{2}=0.12 \text { SE }-032 \text {. DW }-176, \hat{\rho}, 1,00
\end{aligned}
$$

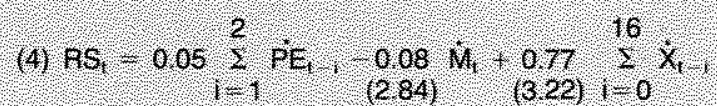

$$
\begin{aligned}
& \text { (5.62) } 107.9 \text { ? }
\end{aligned}
$$

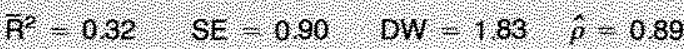

$$
\begin{aligned}
& \text { (5) } \mathrm{U}_{\mathrm{f}} \text { UT }-0.29 \mathrm{GAP}, 0.14 \mathrm{GAP} \text { ? } \\
& (1485) \cup \checkmark \checkmark \checkmark(6.84)
\end{aligned}
$$

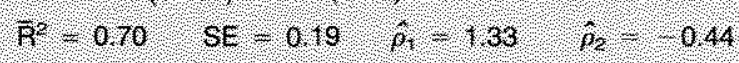

$\checkmark \checkmark$ nominal GNP

$\mathrm{W}$ thoner stock $(\mathrm{m})$

E $=$ high employment expenditures

P / TNP deflator $(1972$ ? 100$)$

PE 4 relathe price of enercy

$x$, output in 1972 dollars.

XF - potential outpu (Rasehehatom)

$\mathrm{nL}$ - corporate bond rate

hS 4 commercial paper rate

$\mathrm{O}=\mathrm{u}$ uempleyment ate.

$\mathrm{UF}$ s unemployment rate at Gil employmen 